\title{
Hematologic alteration in ICU and non-ICU patients of COVID-19
}

Zahra Mozaheb ${ }^{1}$, Abolghasem Allahyari², Mehrdad Sahranavard ${ }^{2}$ Hossein Rahimi $^{3}$, Alireza Bari ${ }^{2}$, mostafa kamandi ${ }^{2}$, sajad ataei azimi ${ }^{2}$, mohammad moeini nodeh ${ }^{4}$, mohsed seddigh-shamsi $^{2}$, ghazaleh ghorbannezhad ${ }^{2}$, Amir hossein barjasteh ${ }^{2}$, and Mohammad Zamiri Bidari ${ }^{5}$

${ }^{1}$ Mashhad University of Medical Sciences

${ }^{2}$ Affiliation not available

${ }^{3}$ MUMS

${ }^{4}$ Mashhad University of Medical Sciences Ghaem Hospital

${ }^{5}$ Mashhad University of Medical Sciences Faculty of Medicine

July 7, 2020

\begin{abstract}
Corona virus spread easily and rapidly over countries and caused COVID-19 disease with several organ damage. Lymphopenia and elevation NLR, LDH and CRP in covid 19 patients could be a predictive factor, and when they become deeper during hospitalization show the patients to need ICU admission.
\end{abstract}

\section{Hosted file}

manuscript main1.docx available at https://authorea.com/users/339634/articles/465776hematologic-alteration-in-icu-and-non-icu-patients-of-covid-19

\section{Hosted file}

main file.docx available at https://authorea.com/users/339634/articles/465776-hematologicalteration-in-icu-and-non-icu-patients-of-covid-19

\section{Hosted file}

Table 1.docx available at https://authorea.com/users/339634/articles/465776-hematologicalteration-in-icu-and-non-icu-patients-of-covid-19

\section{Hosted file}

Table2.docx available at https://authorea.com/users/339634/articles/465776-hematologicalteration-in-icu-and-non-icu-patients-of-covid-19

\section{Hosted file}

Table3.docx available at https://authorea.com/users/339634/articles/465776-hematologicalteration-in-icu-and-non-icu-patients-of-covid-19

\section{Hosted file}

Figure1-5.docx available at https://authorea.com/users/339634/articles/465776-hematologicalteration-in-icu-and-non-icu-patients-of-covid-19 